\title{
Evaluating the suitability of fyke nets for small-scale fisheries in the Free State Province of South Africa
}

\author{
LM Barkhuizen ${ }^{1,2}$ and OLF Weyl ${ }^{3}$ \\ 'Department of Zoology and Entomology, University of the Free State, P.O. Box 339, Bloemfontein, 9300, South Africa \\ ${ }^{2}$ Free State Department of Economic, Small Business Development, Tourism and Environmental Affairs, Private Bag X20801, \\ Bloemfontein, 9300, South Africa \\ ${ }^{3}$ DST/NRF Research Chair in Inland Fisheries and Freshwater Ecology, South African Institute of Aquatic Biodiversity (SAIAB), Private Bag \\ X1015, Makhanda, 6140, South Africa
}

\begin{abstract}
South Africa is under increasing pressure to develop small-scale fisheries in inland waters. To inform appropriate development of this sector in the Free State Province, the catch rate of double-ended fyke nets was evaluated using survey data from 20 impoundments sampled during the 2013/2014 summer season. Fyke nets were set over night and the total sample effort was 114 fyke net nights. Overall catch per unit effort (CPUE) was $16.8 \pm 28.3 \mathrm{~kg} \cdot$ net $^{-1} \cdot$ night $^{-1}$ and catch composition was dependent on impoundment, but generally comprised of a mixture of common carp Cyprinus carpio, African sharptooth catfish Clarias gariepinus, smallmouth yellowfish Labeobarbus aeneus, Orange River mudfish Labeo capensis and moggel Labeo umbratus. The influence of temperature and the potential benefits of baiting the nets were subsequently evaluated through monthly sampling in the hyper-eutrophic Krugersdrift Dam and the oligotrophic Gariep Dam. Baiting did not significantly influence CPUE, which was significantly higher at Krugersdrift Dam $\left(19.97 \pm 23.22 \mathrm{~kg} \cdot \mathrm{net}^{-1} \cdot \mathrm{night}^{-1}\right)$

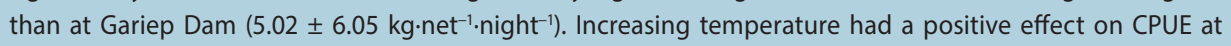
Krugersdrift Dam but not at Gariep Dam. Species composition also differed between impoundments and, as a result, we conclude that seasonal catch rates and species compositions will need to be evaluated prior to implementation of fyke net fisheries in specific localities.
\end{abstract}

\section{INTRODUCTION}

South Africa is under increasing pressure to develop small-scale fisheries in inland waters as an avenue for food security and poverty alleviation (Weyl et al., 2007; McCafferty et al., 2012; Britz et al., 2015). As a result, there has been an increased interest in fisheries development, the focus of which includes investigating avenues for increasing catch rates beyond those attainable from angling. The fyke net, a passive gear consisting of one or two valve traps interconnected by a guide net, is used to harvest a variety of fish species by small-scale fisheries in other parts of the world (Hubert et al., 2012). In the former USSR for example, fyke nets were popular fishing methods due to their simple design, low cost and simple construction (Berka, 1990). In Sweden, fyke nets are used extensively in eel fisheries (Königson et al., 2007) and in Canada they are used by commercial fishers to target a variety of species (Colotelo et al., 2013).

Apart from anecdotal reports on the use of fyke nets to attempt to establish an eel fishery in the Eastern Cape Province (Booth and Potts, 2006), there is no information on their use in fisheries development in South Africa where freshwater fishes have generally been harvested by angling or by gill netting and beach seining (Barkhuizen et al., 2016). Fyke nets have, however, been widely used as a sampling gear in South Africa. Hamman (1974) evaluated fyke nets as a sampling method in the Gariep Dam, but considered their catch rates too low to be of interest as a sampling gear. More recently, Booth and Potts (2006) used fyke nets as an alternative non-destructive sampling method to determine the selectivity of gill nets. Olds et al. (2011) used fyke nets in the Wilderness Lakes System in the Western Cape Province as a sampling gear to determine the status of invasive species, while Ellender et al. (2016) reported on the use of fyke nets in eel surveys.

In this paper, the potential of fyke nets as a low-cost small-scale fisheries gear that is easy to deploy in shallow water without the requirement of a boat is evaluated in two experiments. The first was a broad-scale assessment during the 2013/2014 summer season using un-baited fyke nets in 20 impoundments in the Free State Province to provide an overall indication of their suitability. The second was an in-depth assessment of seasonal catch rates from baited and un-baited fyke nets in the oligotrophic Gariep Dam and hypereutrophic Krugersdrift Dam which were sampled over a 12-month period during 2015/2016.

\section{MATERIALS AND METHODS}

\section{Study area}

The localities of the 20 impoundments that were surveyed during 2013/2014, are indicated in Fig. 1. The two study sites of the 2015/2016 survey are encircled within the figure. Krugersdrift Dam is a

\section{CORRESPONDENCE}

LM Barkhuizen

EMAIL

barkhl@destea.gov.za

\section{DATES}

Received: 25 April 2019

Accepted: 15 November 2019

\section{KEYWORDS}

small-scale fisheries fyke net catch rate catch composition Clarias gariepinus Cyprinus carpio

\section{COPYRIGHT}

(C) The Author(s) Published under a Creative Commons Attribution 4.0 International Licence (CC BY 4.0) 
hyper-eutrophic impoundment that is important for recreational fisheries, situated approximately $30 \mathrm{~km}$ from Bloemfontein (Barkhuizen et al., 2017). It is the receiving impoundment of most of the treated (and sometimes untreated) sewage from wastewater works within the Mangaung Metropolitan Municipality. Water from the impoundment is mostly used for irrigation. Gariep Dam, the largest impoundment in South Africa, is situated approximately $200 \mathrm{~km}$ south of Bloemfontein. There are few urban areas and limited irrigation and industrial activities within the catchment of the impoundment, which is considered to be oligotrophic. The Department of Water and Sanitation monitors and controls the water level with daily releases through the hydro-power station, and regular releases through the Orange-Fish River Inter-Basin Water Transfer Scheme. Small-scale (subsistence) fisheries are the most important fisheries sector, while the dam is also important for recreational angling (Ellender et al., 2010a). At sampling sites in Krugersdrift Dam the substrate consisted of sand and/or mud, while at Gariep Dam the substrate consisted of fine gravel, shale and/or mud.

According to Barkhuizen (2015), freshwater fish communities at impoundments in the Free State are dominated by cyprinids, i.e., smallmouth yellowfish Labeobarbus aeneus, Orange River mudfish Labeo capensis, moggel Labeo umbratus and largemouth yellowfish Labeobarbus kimberleyensis. The alien and invasive common carp Cyprinus carpio is the dominant species at many impoundments and with African catfish Clarias gariepinus they often form the bulk of recreational and small-scale fisheries catches (Ellender et al., 2010b; Barkhuizen, 2015)

\section{Gear used}

During the 2013/2014 summer season's surveys at 20 impoundments, three double-ended Dutch-type fyke nets with a $9.7 \mathrm{~m}$ guiding (leader) net between the hoop nets which were $1 \mathrm{~m}$ high $\times 1.5 \mathrm{~m}$ wide were used. Nets were set between 15:00 and 17:00 on Day 1, checked and re-set between 08:00 and 10:00 on Day 2 and finally lifted between 08:00 and 10:00 on Day 3 .
Total sampling effort was 114 net nights. The netting material in the guiding net and covering both sections had a stretched mesh size of $20 \mathrm{~mm}$, while a section of the netting material at the entrances was made from stronger twine with a stretched mesh size of $25 \mathrm{~mm}$. Otter guards were removed to allow for all sizes of fish to be caught. Anchors were tied to the end ropes of each section to secure the net in its position. To emulate their potential use in small-scale fisheries, the nets were set by wading into the water and when the correct depth (1 to $1.5 \mathrm{~m}$ ) was reached, the first hoops were set first. Each section was then pulled to its maximum to open the cone-shaped netting bags by moving backwards to ensure the bags and the guiding net between the two hoop nets were straight and tight before the anchors were released. All fyke nets were set parallel to the shoreline.

\section{Fish samples}

Fish caught were placed in separate containers, identified to species level and measured for fork and total length to the nearest millimetre. The weight was recorded using an Ishida IPC 1356 scale with maximum capacity of $15 \mathrm{~kg}$ and graduations of $5 \mathrm{~g}$. Smaller specimens were weighed using a Terraillon T800 scale with a maximum capacity of $3 \mathrm{~kg}$ and graduations of $1 \mathrm{~g}$, while specimens $>15 \mathrm{~kg}$ were weighed with a basic spring balance.

\section{Seasonal surveys}

Seasonal surveys were conducted at Krugersdrift Dam and Gariep Dam which were sampled between December 2015 and November 2016. Fyke nets were set in the same way as during the larger survey, but in this case two of the three fyke nets were baited. One net was baited with $500 \mathrm{~g}$ uncooked maize which was scattered in front and inside the first hoop and next to the guiding net, and the other with 8 dead fish weighing between $500 \mathrm{~g}$ and $1 \mathrm{~kg}$ (L. umbratus and L. capensis) placed halfway between the entrance and end of the net. Nets were set for three to four netting nights, lifted once per day, re-baited and reset immediately. Surveys were conducted monthly.

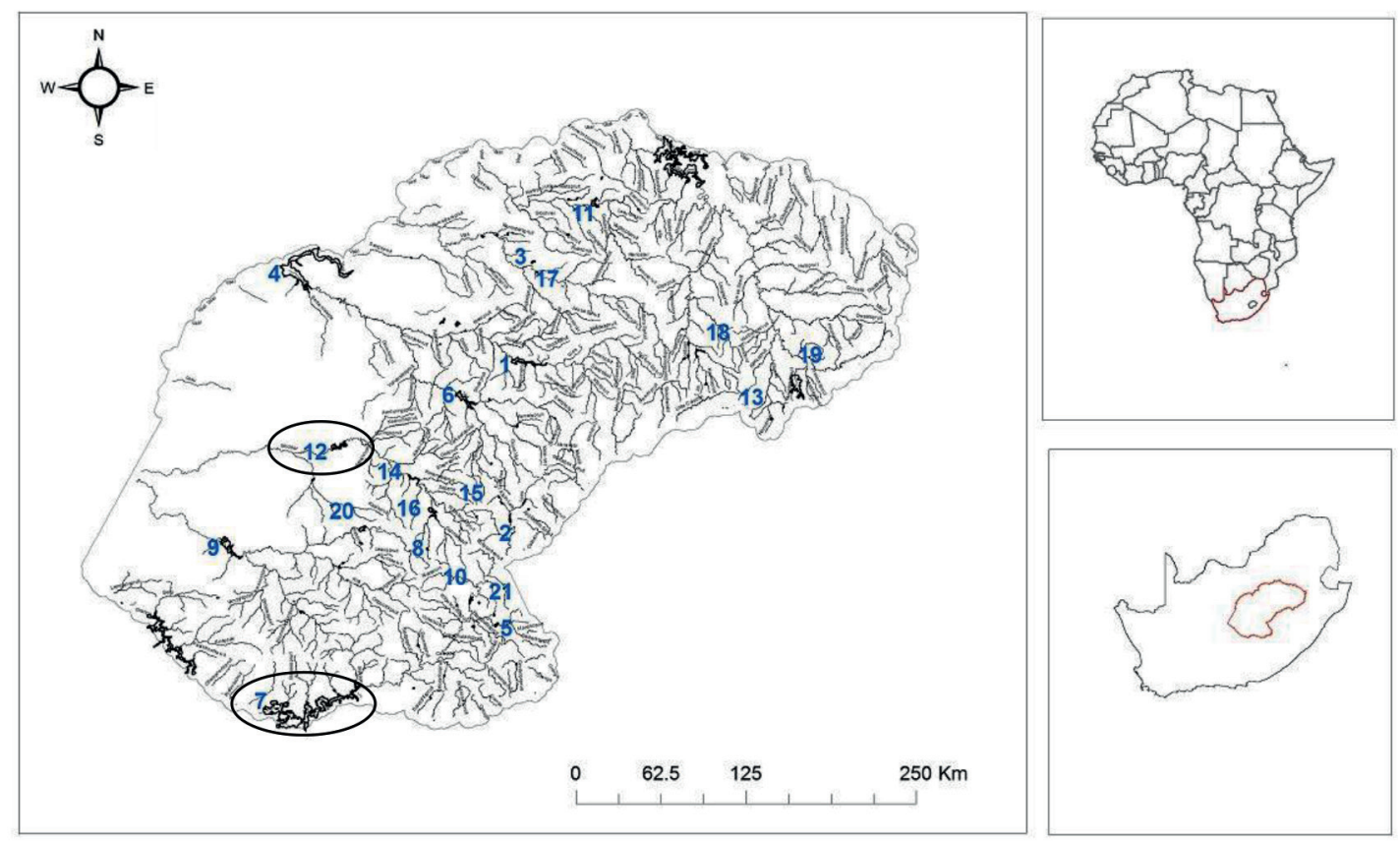

Figure 1. Map indicating the locality of the 20 impoundments that were selected for the 2013/2014 and 2015/2016 studies in the Free State Province of South Africa. The two impoundments that were surveyed during the 2015/2016 study are circled and in bold below. (1 Allemanskraal; 2 - Armenia; 3 - Bloemhoek; 4 - Bloemhof; 5 - Egmont; 6 - Erfenis; 7 - Gariep; 8 - Jimmie Roos; 9 - Kalkfontein; 10 - Knellpoort; 11 - Koppies; 12 - Krugersdrift; 13 - Metsi Matso; 14 - Mockes; 15 - Moutloatsi Setlogelo; 16 - Rustfontein; 17 - Serfontein; 18 - Sol Plaatje; 19 - Sterkfontein; 20 - Tierpoort). 


\section{Statistical analyses}

Catches were standardized to catch per unit effort (CPUE) and expressed as $\mathrm{kg} \cdot \mathrm{net}^{-1} \cdot \mathrm{night}^{-1}$. Seasonal comparisons between Krugersdrift Dam and Gariep Dam and the effect of temperature and bait on catch rate data were assessed using multiple linear regression analysis with temperature and bait type as independent variables and CPUE as the dependent variable. To conform with the assumption of constant variance the data were $\log (n+1)$ transformed. Linear regressions were also performed on a dam-specific basis with temperature as the independent and CPUE as the dependent variable. Pairwise comparisons between the dams were undertaken using the Mann-Whitney $U$-test as data were non-parametric. All analyses were done using the analysis add-on in Sigma Plot for Windows Version 13 (Systat Software Inc.).

\section{RESULTS}

\section{Overall fish catches}

A summary of the physical attributes, catch and species composition (by weight) from fyke nets set in the 20 impoundments is provided in Table 1. No catches were recorded at Metsi Matso Dam and only two fish were recorded at Sterkfontein Dam. The highest CPUE was from Koppies Dam $\left(101.8 \pm 313.9 \mathrm{~kg} \cdot\right.$ net $^{-1} \cdot$ night $\left.^{-1}\right)$. Overall CPUE was $16.8 \pm 28.3$ $\mathrm{kg} \cdot$ net $^{-1} \cdot$ night $^{-1}$ and was dependent on impoundment, and species composition was generally comprised of a mixture of C. carpio (0.03 - 79.6\%), C. gariepinus (0.2-89.6\%), L. aeneus (0.1-18.4\%) and two Labeos, i.e., L. capensis and L. umbratus (0.03-94.2\%). At 9 impoundments, C. gariepinus dominated the catches while the combination of the two Labeo species, i.e., L. capensis and L. umbratus, dominated catches at 8 impoundments. Cyprinus carpio only dominated catches at Sol Plaatje Dam. Other species were an incidental component, generally making up $<1 \%$ of the total catch.

\section{Seasonal surveys in Krugersdrift and Gariep Dams}

A summary of the catch data in seasonal surveys is provided in Table 2 for Krugersdrift Dam and Gariep Dam. Multiple linear regressions revealed that the inclusion of bait had no significant effect on CPUE $(P=0.97)$ but that CPUE was significantly correlated with temperature $(P \leq 0.001)$ and dam $(P \leq 0.001)$. Overall nets set at Krugersdrift Dam had a significantly higher CPUE $\left(19.97 \pm 23.22 \mathrm{~kg} \cdot\right.$ net $^{-1} \cdot$ night $\left.^{-1}\right)$ than those set at Gariep Dam

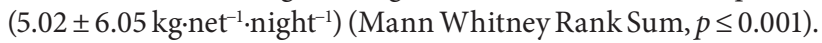
The effects of temperature on fyke net CPUE in the two dams are

Table 1. Parameters recorded, CPUE and species composition (\% weight) for 2013/2014 survey at 20 impoundments

\begin{tabular}{|c|c|c|c|c|c|c|c|c|c|c|c|}
\hline \multirow{2}{*}{$\begin{array}{l}\text { Name of } \\
\text { impoundment }\end{array}$} & \multirow{2}{*}{$\begin{array}{l}\text { Netting } \\
\text { nights }\end{array}$} & \multirow{2}{*}{$\begin{array}{l}\text { Size } \\
\text { (ha) }\end{array}$} & \multirow{2}{*}{$\begin{array}{c}\text { Water } \\
\text { level (\%) }\end{array}$} & \multirow{2}{*}{$\begin{array}{c}\text { Secchi } \\
\text { depth }(\mathrm{cm})\end{array}$} & \multirow{2}{*}{$\begin{array}{c}\text { Water } \\
\text { temp. }\left({ }^{\circ} \mathrm{C}\right)\end{array}$} & \multirow{2}{*}{$\begin{array}{c}\text { CPUE } \\
\left(\mathrm{kg} \cdot \mathrm{net}^{-1} \cdot \mathrm{day}^{-1}\right)\end{array}$} & \multicolumn{5}{|c|}{ Species composition (\%weight) } \\
\hline & & & & & & & Carp & Catfish & SMYF & Labeos & Other \\
\hline Allemanskraal & 6 & 2667 & 17.3 & 20 & 20.7 & 4.5 & 4.9 & 0.2 & 0.1 & 94.2 & 0.6 \\
\hline Armenia & 6 & 393 & 15.9 & 9 & 23.8 & 3.4 & 2.4 & 8.2 & 16.6 & 70 & 2.8 \\
\hline Bloemhoek & 6 & 370 & 20 & 31 & 26.2 & 8.8 & 30.6 & 40.1 & 0 & 24.9 & 4.4 \\
\hline Bloemhof & 6 & 23067 & 36 & 34 & 27.8 & 62.9 & 10.4 & 89.6 & 0 & 0.03 & 0 \\
\hline Egmont & 6 & 244 & 54.5 & 7 & 26.9 & 15.9 & 1.6 & 3 & 8.1 & 87.3 & 0 \\
\hline Erfenis & 6 & 3291 & 23.1 & 14 & 20.7 & 7.0 & 6.2 & 0 & 18.4 & 60.5 & 14.9 \\
\hline Gariep & 6 & 35216 & 78 & 30 & 27.0 & 17.7 & 27.1 & 67 & 4.5 & 1.4 & 0 \\
\hline Jimmie Roos & 6 & 115 & 50 & 22 & 24.1 & 23.9 & 17.2 & 13.4 & 0 & 69.4 & 0.01 \\
\hline Kalkfontein & 6 & 3769 & 37.9 & 30 & 25.7 & 6.6 & 3.1 & 19.4 & 0 & 77.5 & 0 \\
\hline Knellpoort & 6 & 977 & 42.9 & 34 & 24.5 & 13.3 & 3.9 & 0 & 1.6 & 88.9 & 5.6 \\
\hline Koppies & 6 & 1439 & 58.3 & 20 & 23.0 & 101.8 & 4.5 & 87 & 0.3 & 8.1 & 0.1 \\
\hline Krugersdrift & 6 & 1853 & 29.7 & 40 & 21.9 & 21 & 27.1 & 60.7 & 0 & 12.14 & 0.06 \\
\hline Metsi Matso & 6 & 66 & 100 & $>200$ & 24.1 & 0 & 0 & 0 & 0 & 0 & 0 \\
\hline Mockes & 6 & 147 & 100 & 10 & 26.6 & 7.7 & 29.2 & 64.2 & 0.2 & 5.5 & 0.9 \\
\hline Moutloatsi Setlogelo & 6 & 250 & 10.2 & 19 & 20.8 & 9.9 & 0.03 & 57.9 & 0 & 41.2 & 0.87 \\
\hline Rustfontein & 6 & 1159 & 27.3 & 25 & 19.0 & 0.9 & 11.8 & 0 & 2.2 & 85.5 & 0.5 \\
\hline Serfontein & 3 & 142 & 100 & 10 & 29.6 & 19.2 & 27.7 & 71 & 0.03 & 1.3 & 0 \\
\hline Sol Plaatjie & 6 & 356 & 100 & 37 & 17.9 & 0.9 & 79.6 & 0 & 0.2 & 20.2 & 0 \\
\hline Sterkfontein & 6 & 6937 & 100 & $>200$ & 19.6 & 0.5 & 0 & 0 & 0 & 0 & 100 \\
\hline Tierpoort & 3 & 911 & 12.4 & 28 & 24.5 & 12.0 & 32.7 & 59.4 & 1.1 & 6.1 & 0.7 \\
\hline
\end{tabular}

Key: carp - C. carpio; catfish - C. gariepinus; SMYF- L. aeneus; Labeos - L. capensis and L. umbratus

Others: L. kimberleyensis, straightfin barb Enteromius paludinosus, southern mouthbrooder Pseudocrenilabrus philander

Table 2. Fish species' contribution to the total weight (\%) of the total catch, and CPUE $\left(\mathrm{kg} \cdot \mathrm{net}^{-1} \cdot \mathrm{night}^{-1}\right)$ during the seasonal study for Krugersdrift Dam and Gariep Dam

\begin{tabular}{|c|c|c|c|c|c|c|}
\hline \multirow[b]{2}{*}{ Fish species } & \multicolumn{3}{|c|}{ Gariep Dam } & \multicolumn{3}{|c|}{ Krugersdrift Dam } \\
\hline & $\begin{array}{c}\text { Total weight } \\
(\mathrm{kg})\end{array}$ & $\begin{array}{l}\text { Percentage of } \\
\text { total weight }\end{array}$ & CPUE & $\begin{array}{c}\text { Total weight } \\
(\mathrm{kg})\end{array}$ & $\begin{array}{c}\text { Percentage of } \\
\text { total weight }\end{array}$ & CPUE \\
\hline C. carpio & 25.5 & 4.5 & 0.08 & 1023.9 & 34.8 & 2.5 \\
\hline C.gariepinus & 209.5 & 37 & 0.6 & 1360.7 & 46.3 & 3.3 \\
\hline L. aeneus & 216.5 & 38.3 & 0.7 & 2.2 & 0.1 & 0.005 \\
\hline Labeos & 107.7 & 19 & 0.3 & 55.2 & 18.8 & 0.13 \\
\hline * Other & 6.6 & 1.2 & 0.02 & 0.8 & 0 & 0.002 \\
\hline
\end{tabular}

* Other: Gariep Dam: L. kimberleyensis; Krugersdrift Dam: P. philander 
illustrated in Fig. 2. Temperature significantly influenced fyke net CPUE in Krugersdrift Dam (linear regression: $P \leq 0.01, r^{2}=0.36$ ) but not in Gariep Dam (linear regression: $P=0.10, r^{2}=0.08$ ). At Gariep Dam, the overall catch during the seasonal survey were dominated by $L$. aeneus (38.3\%), followed by C. gariepinus (37\%). The overall catch at Krugersdrift Dam was dominated by C. gariepinus (46.3\%), followed by C. carpio (34.8\%).

\section{DISCUSSION}

Small-scale fishing is on the increase at most state dams in the Free State Province (Barkhuizen 2015). Most small-scale fishers harvest the resource by angling and, as reported by Ellender et al. (2010b), the expected end-of-day catch ranges between 2.2 and $6.4 \mathrm{~kg} \cdot \mathrm{angler}^{-1} \cdot \mathrm{d}^{-1}$ depending on sampling period. However, angling requires active participation which reduces time available for other income-generating activities. In South Africa the use of gill nets, a passive gear widely used in small-scale fisheries in Africa (Tweddle et al., 2015), remains controversial as their bycatch can include threatened fishes and other nontarget taxa including birds, reptiles (e.g. Ellender et al., 2012; Ellender et al., 2016) and otters (Barkhuizen, 2015). In addition, unsustainable gill netting may cause major stock reductions to the detriment of species, the ecosystem and other users of the resource, e.g., recreational and subsistence angling. With an average CPUE approximating $16.8 \pm 28.3 \mathrm{~kg} \cdot$ net $^{-1} \cdot$ night $^{-1}$ across 20 impoundments, the data from the current study suggests that fyke nets may have some utility as passive gear for use in smallscale fisheries. However, as indicated in Table 1, CPUE and species composition will vary between impoundments because of differences in productivity and fish abundance. Therefore, this gear will not be suitable for use in all impoundments. For example, at impoundments with clear water (Secchi depth > $200 \mathrm{~cm}$ ) and with steep banks (e.g. Sterkfontein and Metsi Matso Dams) the lowest CPUE was recorded.

South Africa's draft inland fisheries policy looks towards inland fisheries as a source of food security and livelihoods for smallscale fishers. Extrapolating from a fish price of $17 \mathrm{ZAR} / \mathrm{kg}$ (based on sales price in the previous Gariep Dam fishery projects, LM Barkhuizen personal observation), the mean catch value of ZAR285/day substantially exceeds the proposed minimum rural wage of $160 \mathrm{ZAR} /$ day (SAnews, 2018). Variation in catch rates between dams, however, suggests that while double-ended fyke nets may be a useful gear in small-scale fisheries on dams, localityspecific data will be necessary. This will prevent misguided development and unrealistic stakeholder expectations in localities where catch rates are likely to be too low (e.g. Sterkfontein and Metsi Matso Dams) to compensate for opportunity costs, which would contribute to the legacy of failure in inland fisheries development in South Africa (Barkhuizen et al., 2016).

This is demonstrated in the comparative assessment of the Gariep and Krugersdrift Dams. In Krugersdrift Dam, for example, catch was dominated by C. carpio and C. gariepinus, neither of which is a conservation priority species and both of which have established marketability (see Weyl et al., 2007; Ellender et al., 2010a). CPUE was generally high $\left(19.97 \pm 23.22 \mathrm{~kg} \cdot\right.$ net $^{-1} \cdot$ night $\left.^{-1}\right)$ but with a significant trend of increased CPUE with increasing temperature (Fig. 2). Here the use of fyke nets is likely to result in a productive (and profitable) enterprise for participants, should it be permitted. In Gariep Dam, on the other hand, the generally low $\left(5.02 \pm 6.05 \mathrm{~kg} \cdot\right.$ net $^{-1} \cdot$ night $\left.^{-1}\right)$ CPUE was maintained throughout the year (Fig. 2). In addition, more than half of the catch consisted of L. aeneus and Labeos (Table 2). This was unexpected as during the broad-scale summer survey these species made up only $6 \%$ of the total catch (see Table 1) and illustrates the weakness of rapid assessments for decision

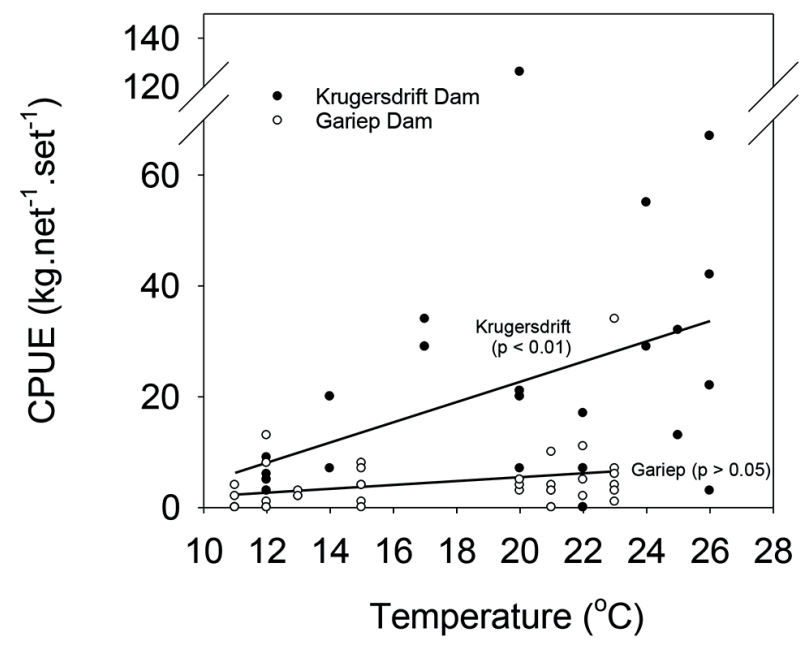

Figure 2. Scatterplot of fyke net CPUE in relation to temperature at Krugersdrift Dam and Gariep Dam for the period December 2015 until November 2016

making. Although these species are widespread and abundant, $L$. aeneus is considered a conservation-priority species and harvests in the Free State Province are regulated (Barkhuizen, 2015). In this case assessments of profitability may need to incorporate the release of a relatively high proportion of the catch. It is therefore imperative that comprehensive surveys are conducted on dams where the implementation of fyke nets are being considered as gears for small-scale fishers.

Within the development and eventual implementation of the National Inland Fisheries Policy in South Africa, fyke nets could be considered as an alternative gear to gill nets as they are less destructive and allow for the release of threatened and protected species with little to no harm. However, it is recommended that small-scale fishery projects using this gear be monitored and regulated as per the envisaged regulations emanating from the National Inland Fisheries Policy.

\section{ACKNOWLEDGEMENTS}

LMB thanks the FS DESTEA for support during the study on fish and inland fisheries in the Orange-Senqu River Basin and permission to do the fish surveys under permit number $01 / 28643$. OLFW acknowledges use of infrastructure and equipment provided by the SAIAB Research Platform and the funding channelled through the NRF-SAIAB Institutional Support system. This study was partially funded by the National Research Foundation - South African Research Chairs Initiative of the Department of Science and Technology (Inland Fisheries and Freshwater Ecology, Grant No. 110507). Any opinions, findings, conclusions or recommendations expressed in this material are those of the authors, and the FS DESTEA, UFS and NRF do not accept any liability in this regard.

\section{REFERENCES}

BARKHUIZEN LM (2015) An assessment of fish and fisheries in impoundments in the Upper Orange-Senqu and lower Vaal River Basin. PhD thesis, University of the Free State, Bloemfontein.

BARKHUIZEN LM, WEYL OLF and VAN AS JG (2016) A qualitative and quantitative analysis of historic commercial fisheries in the Free State Province in South Africa. Water SA 42 (4) 601-605. https://doi. org/10.4314/wsa.v42i4.10

BARKHUIZEN LM, WEYL OLF and VAN AS JG (2017) An assessment of recreational bank angling in the Free State Province in South Africa using license sale and tournament data. Water SA 43 (3) $442-$ 449. https://doi.org/10.4314/wsa.v43i3.09 
BERKA R (1990) Inland capture fisheries of the USSR. FAO Fisheries Technical Paper 311. FAO, Rome.

BOOTH AJ and POTTS WM (2006) Estimating gill-net selectivity for Labeo umbratus (Pisces: Cyprinidae), and an evaluation of using fyke-nets as a non-destructive sampling gear in small reservoirs. Fish. Res. 79 202-209. https://doi.org/10.1016/j.fishres.2006.02.015

BRITZ PJ, HARA MM, WEYL OLF, TAPELA BN and ROUHANI Q (2015) Scoping study on the development and sustainable utilisation of inland fisheries in South Africa. Volume 1: Scoping Report. WRC Report No. TT 615-1-14. Water Research Commission, Pretoria.

COLOTELO AH, RABY GD, HASLER CT, HAXTON TJ, SMOKOROWSKI KE, BLOUI-DEMERS $G$ and COOKE ST (2013) Northern pike bycatch in an inland commercial hoop net fishery: effects of water temperature and net tending frequency on injury, physiology, and survival. Fish. Res. 137 41-49. https://doi. org/10.1016/j.fishres.2012.08.019

ELLENDER BR, WEYL OLF, WINKER H and BOOTH AJ (2010a) Quantifying the annual fish harvest from South Africa's largest freshwater reservoir. Water SA 36 (1) 45-51. https://doi.org/10.4314/ wsa.v36i1.50906

ELLENDER BR, WEYL OLF, WINKER H, STELZHAMMER H and TRAAS GRL (2010b) Estimating angling effort and participation in a multi-user, inland fishery in South Africa. Fish. Manage. Ecol. 17 19-27. https://doi.org/10.1111/j.1365-2400.2009.00708.x

ELLENDER BR, WEYL OLF and WINKER H (2012) Age and growth and maturity of southern Africa's largest cyprinid fish, the largemouth yellowfish Labeobarbus kimberleyensis. J. Fish Biol. 81 1271-1284. https://doi.org/10.1111/j.1095-8649.2012.03395.x

ELLENDER BR, WASSERMAN RJ, NDALENI PM, MOFU L, WU A and WEYL OLF (2016) Reporting by-catch and mortalities in targeted biological field surveys on fishes. Aquat. Conserv. Mar. Freshwater Ecosyst. 26 596-601. https://doi.org/10.1002/aqc.2613

HAMMAN KCD (1974) 'n Ondersoek na die lengte, massa, ouderdom en, gonade-ontwikkeling van die groter visspesies in die H.F. Verwoerddam. (In Afrikaans.) MSc dissertation. Randse Afrikaanse Universiteit, Johannesburg.

HUBERT WA, POPE KL and DETTMERS JM (2012) Passive capture techniques. In: Zale AV, Parrish Dl and Sutton TM (eds). Fisheries Techniques $\left(3^{\text {rd }}\right.$ edn). American Fisheries Society. Bethesda, Maryland.

KöNIGSON S, HEMMINGSON M, LUNNERYD S and LUNDSTRöM K (2007) Seals and fyke nets: an investigation of the problem and its possible solution. Mar. Biol. Res. 3 29-36. https://doi. org/10.1080/17451000601072596

McCAFFERTY JR, ELLENDER BR, WEYL OLF and BRITZ P (2012) The use of water resources for inland fisheries in South Africa. Water SA 38 (2) 327-344. https://doi.org/10.4314/wsa.v38i2.18

OLDS AA, SMITH MKS, WEYL OLF and RUSSEL IA (2011) Invasive alien freshwater fishes in the Wilderness Lakes System, a wetland of international importance in the Western Cape Province, South Africa. Afr. Zool. 46 (1) 179-184. https://doi. org/10.3377/004.046.0109

SAnews (2018) https://www.sanews.gov.za (Accessed 6 February 2019).

TWEDDLE D, COWX IG, PEEL RA and WEYL OLF (2015) Challenges in fisheries management in the Zambezi, one of the great rivers of Africa. Fish. Manage. Ecol. 22 99-111. https://doi.org/10.1111/ fme. 12107

WEYL OLF, POTTS W, ROUHANI Q and BRITZ P (2007) The need for inland fisheries policy in South Africa: A case study of the North West Province. Water SA 33 (4) 1-8. 